Research Article

\title{
A new species of Phasmatocoris Breddin, 1904 (Hemiptera: Heteroptera: Reduviidae: Emesinae) from Ecuador, with taxonomic notes and an updated key of the genus
}

Una nueva especie de Phasmatocoris Breddin, 1904 (Hemiptera: Heteroptera: Reduviidae: Emesinae) de Ecuador, con notas taxonómicas y una clave actualizada del género

\author{
Hélcio R. Gil-Santana ${ }^{1}$
}

\begin{abstract}
${ }^{1}$ Laboratório de Diptera, Instituto Oswaldo Cruz, Av. Brasil,4365,21040-360, Riode Janeiro, Brazil.院helciogil@ uol.com.br; helciogil@ioc.fiocruz.br
\end{abstract}

ZooBank: urn:lsid:zoobank.org:pub:9D52A173-4792-4A6A-9CDF-7B1EF5F5C38F

https: / / doi.org/ 10.35249/ rche.47.3.21.16

\begin{abstract}
Phasmatocoris ecuadorensis sp. nov. (Hemiptera: Heteroptera: Reduviidae: Emesinae) is described from Ecuador based on a male specimen. Phasmatocoris Breddin, 1904 is recorded from Ecuador for the first time. Short taxonomical notes on Phasmatocoris praecellens (Bergroth, 1911) are provided. An updated key to the species of Phasmatocoris is presented.
\end{abstract}

Key words: Emesini; Neotropical region; taxonomy.

Resumen. Basado en un ejemplar macho se describe a Phasmatocoris ecuadorensis sp. nov. (Hemiptera: Heteroptera: Reduviidae: Emesinae) de Ecuador. Phasmatocoris Breddin, 1904 es registrado por primera vez para Ecuador. Se proveen breves notas taxonómicas sobre Phasmatocoris praecellens (Bergroth, 1911) y una clave actualizada para las especies de Phasmatocoris.

Palabras clave: Emesini; región Neotropical; taxonomía.

\section{Introduction}

Wygodzinsky (1966) provided a detailed redescription of Phasmatocoris Breddin, 1904, and included Rothbergia McAtee \& Malloch, 1925 and Myiagreutes Bergroth, 1911 as junior synonyms of the former genus. Pape (2013) and Gil-Santana (2015) added minor modifications to its description.

Currently, Phasmatocoris Breddin, 1904 (Hemiptera: Heteroptera: Reduviidae: Emesinae: Emesini) includes 18 species (Wygodzinsky 1966; Maldonado 1990; Gil-Santana et al. 2007; Pape 2013; Gil-Santana 2015, 2018a, 2018b). Among them, only Ph. praecellens (Bergroth, 1911) and Ph. papei Gil-Santana, 2018 have been recorded from French Guiana, while no species of Phasmatocoris was recorded from Ecuador so far (Bergroth 1911; Wygodzinsky 1966; Froeschner 1981; Maldonado 1990; Gil-Santana 2018a).

The dorsal surface of the fore tibiae of many emesines presents a group of serially arranged and obliquely inclined stiff setae somewhat resembling the calamistrum occurring in cribellate spiders. These spiders use the calamistrum as a carding apparatus. The existence

Received 5 August 2021 / Accepted 6 September 2021 / Published online 30 September 2021 Responsible Editor: José Mondaca E. 
of a calamistrum-like structure in the frequently arachnophilous Emesinae is suggestive of a comparable function for this organ (Wygodzinsky 1966). Although the latter author provided a comparative table of the relative position of the calamistrum-like structure on the fore tibiae among 19 species belonging to four tribes in Emesinae, including Ph. minor (McAtee \& Malloch, 1925) and Ph. praecellens, he did not mention this character in his redescription of Phasmatocoris, or in his descriptions of any of the included species in the same work (GilSantana 2015). Forero (2006) described a depression on the dorsal surface of the fore tibiae, covered with medium-sized dense setae, in Ph. spectrum Breddin, 1904, and pointed out that this character was not mentioned by Wygodzinsky (1966). Subsequently, Pape (2013) and Gil-Santana $(2015,2018 \mathrm{a})$ recorded these characteristics in the seven species of Phasmatocoris studied by them. The presence of this structure suggests a potential arachnophilous association, but currently no field observation is available about the bionomics of the species in which it has been recorded (Gil-Santana 2015, 2018a).

Phasmatocoris ecuadorensis sp. nov. is herewith described from Ecuador based on a male specimen. Photographs of the type specimen of Ph. praecellens are presented, with short notes on some of its characteristics. Phasmatocoris Breddin, 1904 is recorded from Ecuador for the first time. An updated key to the species of Phasmatocoris is presented.

\section{Material and Methods}

For the present study, the syntype of Myiagreutes praecellens Bergroth, deposited in the Finnish Museum of Natural History (FMNH), Helsinki, Finland, was examined and partially photographed by the author (Fig. 39). Most of photographs presented here (Figs. 36-38) were taken by Pekka Malinen and supplied by Heidi Viljanen (FMNH) and are available at http: / / id.luomus.fi/GZ.45901.

The holotype of Phasmatocoris ecuadorensis sp. nov. will be deposited in the Entomological Collection of the "Museu Nacional da Universidade Federal do Rio de Janeiro", Rio de Janeiro, Brazil (MNRJ).

Dissections of the male genitalia were made by removing the pygophore from the abdomen with a pair of forceps and then clearing in $\mathrm{NaOH}$ solution for 24 hours. The dissected structures were studied and photographed in glycerol. Images of external and genital structures were taken using digital cameras (Nikon D5600 with a Nikon Macro Lens $105 \mathrm{~mm}$, Sony DSC-W830 and Sony DSC-HX400V). Drawings were made using a camera lucida. The vestiture (setation) was omitted in the ink drawings showing several structures (Figs. 7-8, 16-23), in order to make the shape and / or structure of these portions better visible. The general terminology used here, including for the portions of the male genitalia, are primarily in accordance with Wygodzinsky (1966). However, the (visible) segments of the labium are numbered as II to IV, given that the first segment is lost or fused to the head capsule in Reduviidae (Weirauch 2008). In male genitalia, the dorsal phallothecal plate and basal plate struts (short, struts), as recognized separately by several authors (e.g., Lent and Wygodzinsky 1979) were considered as a single unity, named as basal plate struts by Wygodzinsky (1966). Here, the latter terminology is followed. When describing label data, a slash (/) separates the lines and a double slash (//) different labels.

\section{Results}

\section{Taxonomy}

\section{Genus Phasmatocoris Breddin, 1904}

Phasmatocoris can be separated from other genera of Emesini by the following combination 
of characters: ocelli absent; pronotum more or less constricted between fore and hind lobes, but not pedunculate; scutellum elevated but not spined; metanotum with or without a spine; tarsi three-segmented; wings fully developed; forewings with three closed cells (basal, subbasal and discal cells) (Wygodzinsky 1966).

\section{Phasmatocoris ecuadorensis sp. nov.}

(Figs. 1-35)

Type material. Holotype đ̊ [MNRJ], Ecuador, Pichincha, 18 / V / 1997, Sanchez, P. leg.

Etymology. The specific epithet ecuadorensis is derived from Ecuador, the South American country in which the species was found with the Latin adjectival suffix "-ensis", meaning "pertaining to" or "originating in".

Diagnosis. The male most closely resembles that of Ph. papei Gil-Santana, 2018. The two species can be readily separated by the differences stated in the key below and additionally by the following characteristics of their phalli: 1) basal plate struts (bp) relatively shorter and enlarged, racket-shaped, basal half with subparallel margins, distal half suboval; narrowly to somewhat divided at basal portion and largely divided at apical portion; apical extremities rounded and somewhat asymmetrical in Ph. papei and elongated, generally narrow with basal portion largely divided in two branches, somewhat enlarged in the median portion and even narrower at distal half, which has most of its central portion deepened, bordered by narrow margins, and convergent at the apical extremity in Ph. ecuadorensis n. sp. (Figs. 26, 29-30); 2) The short sclerotization of dorsal wall of phallosoma (sdw) located ventrally and dorsally in relation to the apical portion of basal plate struts in Ph. papei and Ph. ecuadorensis sp. nov., respectively (Figs. 26, 28, 30); 3) Ventral median sclerotization of dorsal wall of phallosoma (sdw) elongated, shortly divided at extreme base, narrowed at approximately middle portion in Ph. ecuadorensis sp. nov. (Figs. 25, 27, 28, 35) and becoming divided in apical third, forming a subsquared, somewhat larger and asymmetrical apical flat process in Ph. papei; 4) Three and only two processes of endosoma in Ph. papei and Ph. ecuadorensis sp. nov., respectively; 5) Dorsal process of endosoma (dps) shorter in P. papei, reaching approximately at level of the middle portion of basal plate struts, while it is more elongated in Ph. ecuadorensis sp. nov., reaching short of the apex of basal plate struts (Figs. 26-28); 6) Basoventral moderately large process of endosoma (bv) flat, with a short narrow striate basomedian portion, surrounded by curved layers, which are distally connected with a pair of flat, narrow laminar portions in Ph. ecuadorensis sp. nov. (Fig. 34), and its equivalent in Ph. papei ("large process of endosoma", according to Gil-Santana 2018a) with a sclerotized elongated core surrounded by filamentous and membranous layers, enlarged at base and somewhat narrowed and asymmetrical towards apical third, in which at one side only there is a somewhat curved sclerotized band.

Description. Measurements: (holotype, in $\mathrm{mm}$ ): total length: to tip of abdomen: 17.5; to tip of forewings: 16.6. Head (excluding neck): length: 1.8; length of anteocular portion: 0.7; length of postocular portion: 0.4 ; width across eyes: 1.4; interocular distance between eyes (synthlipsis): 0.6 ; width of eye: 0.3 ; length of eye: 0.5 ; lengths of antennal segments: I: 11.5 ; II: 10.2.; III: 1.0; IV: 3.3; lengths of labial segments: II [first visible]: 0.3; III: 0.5; IV: 1.1. Thorax: pronotum: fore lobe: length: 2.2; maximum width: 1.0 ; hind lobe: length: 1.9 ; maximum width (at posterior margin): 1.6; length of forewing: 10.9; length of hind wing: 9.8 ; fore legs: length of coxa: 4.4; length of femur: 6.0; length of tibia: 2.8; length of tarsus: 0.9 ; middle legs: length of femur: 11.5; length of tibia: 15.5; length of tarsus: 0.8; hind legs: length of femur: 15.1; length of tibia: 24.0; length of tarsus: 0.8. Abdomen: length: 10.8; maximum width: 1.1. Coloration: general coloration dark brownish to blackish (Figs. 1-6). Head (Figs. 4-5): apices 
of antenniferous tubercles, extreme base of first antennal segment, and labrum pale; last antennal segment basally dark, becoming progressively paler towards apex; small median depressed area present immediately anteriad of transversal sulcus deep black; labium somewhat paler at the junction between segment III (second visible) and IV and at tip of the latter; area just posterior to the eyes reddish brown. Thorax: angles of collar of fore lobe of pronotum dark reddish (Figs. 4,6); anterolateral angles of hind lobe of pronotum with a subtriangular dark yellowish spot, larger anteriorly (Fig. 3). Fore legs: generally brownish, trochanters darker; fore femora paler at medial surface, between the isolated seta and the remaining setae of the anteroventral series, its approximately distal half darker, with a subdistal pale annulus about as long as the width of the segment (Figs. 3, 9); base of tibiae darker; tarsi slightly paler (Figs. 10-11). Middle and hind legs: femora brownish black, becoming darker, blackish towards apices; hind femora with subapical narrow yellowish spots, on lateral and dorsal surfaces, not forming a complete annulus (Fig. 12); tibiae generally blackish, with a pale spot at ventral surface of extreme base and paler at distal portion; tarsi pale. Forewing (Fig. 13): generally dark brown; basal third of basal cell pale whitish; inner margin of pterostigma with reddish tinge, except at its apex; portion of vein $\mathrm{M}$ which runs at the middle third of the wing and $\mathrm{Pcu}+1 \mathrm{~A}$ paler; adjacent portions of mentioned part of vein M, more extensively on outer margin, even paler, whitish at the level in which this vein encloses basal cell and basal portion of discal cell; most portions of $\mathrm{Cu}$ and $\mathrm{M}$ enclosing inner and distal portions of discal cell pale whitish, with adjacent membrane with the same color, which extends posteriorly in the area adjacent to the pterostigma; an additional pale linear marking between discal cell and inner margin of wing; a distal curved vein marked with pale coloration at its median portion. Hind wings hyaline, veins somewhat and variably darkened. Abdomen: distal half of tergite II, tergites III-VI and basal half of VII pale brownish; tongueshaped prolongation of tergite VII dark brownish; connexivum slightly darkened, connexival segments III-VII with small ill-defined basal pale markings; spiracles of the sternites III-VII and the area surrounding them paler; lateral and basolateral portions of sternite VIII and pygophore, respectively, paler. Vestiture: body integument generally covered with a pubescence formed by numerous very short slender adpressed setae and variably scattered longer setae. Head: mostly covered by a pubescence formed by adpressed short thin pale setae, with scattered longer setae on lateral region, clypeus and first visible labial segment. Labial segments III and IV mostly glabrous; the former and the basal and apical portions of the latter with a few scattered straight erect very short pale setae; additionally, a pair of more elongated, curved, pale yellowish setae at apical portion of the segment IV. A group of stouter, moderately longer, dark setae beside anteroventral portion of eye. Glabrous areas on head: transverse sulcus, the portion just anterior to it, including the small median depressed area, and a pair of submedian slightly divergent thin bands running from midportion of transverse sulcus to a point near medial margin of antenniferous tubercles. Antenna generally covered with thin dark setae, longer on the first segment and whitish pale on the last segment, except on basal portion where they are pale brownish. Thorax: fore lobe of pronotum with sparse, short, adpressed, thin pale setae on dorsal and lateral portions; longer thin setae on lobe of acetabula and ventral surface of basal prominent portion of prosternum; hind lobe almost glabrous, with sparse somewhat curved setae on distal portion; meso- and metapleura, pro-, meso- and metasterna covered by a somewhat sparse pubescence formed by short, thin, adpressed small setae; lateral portion of mesosternum glabrous. Legs covered by numerous short to somewhat longer thin setae, pale or dark, similar to the coloration of integument which they are inserted on. Armature of ventral surface of fore femora only with slender spine-like setae in two series, posteroventral and anteroventral, apically transformed into short teeth; anteroventral series interrupted at base, not connected to posteroventral series, one isolated seta basal to interruption (Fig. 9); distance between this latter and first seta of series $0.5 \mathrm{~mm}$; distance from base of fore femur to insertion of first spiniform seta of 
anteroventral series $2.9 \mathrm{~mm}$, and from apex of fore trochanter $2.5 \mathrm{~mm}$. Distance from base of fore femur to insertion of first spiniform seta in posteroventral series, approximately twice longer than length of fore tarsus, $2.0 \mathrm{~mm}$, and from apex of fore trochanter, $1.6 \mathrm{~mm}$. Left femur with an additional [broken] seta between the base of the segment and the posteroventral series (Fig. 9); respective distances between this seta and first seta in posteroventral series, apex of trochanter and base of femur (in $\mathrm{mm}$ ): 0.6 / 1.0 / 1.5. Longer setae in posteroventral series, with length approximately as long as the value of maximum width of fore femur. Fore tibiae (Figs. 10-11) with a cluster of stiff obliquely inclined pale to golden setae on approximately distal half, dorsally, more numerous just basad to depressed area of this portion; numerous straight short setae close beside medial series of denticles ventrally; inner surface on approximately distal fourth, with dense short adpressed golden pubescence and a subapical comb; apex with a dense cluster of golden stiff setae ventrally. Wings glabrous. Abdomen generally covered by a pubescence formed by short, thin, adpressed small setae and scattered longer setae. Pygophore more densely setose. Structure: Integument generally moderately shiny. Head elongated, approximately 1.2 times as long as wide across eyes; anteocular portion longer than postocular (Figs. 4-5); transversal (interocular) sulcus deep, situated at level of distal portion of middle third of eyes (Fig. 4); a small median depressed area present immediately anteriad of it; distance from apex of antenniferous tubercle to anterior border of eye in lateral view $(0.45 \mathrm{~mm})$ slightly shorter than length of eye $(0.5 \mathrm{~mm})$; eyes prominent, projecting laterally, subcircular in dorsal view, reaching dorsal outline of head at interocular sulcus and ventral margin of head (Figs. 4-5). Antennal segments progressively thinner, very slender; segment IV with apex triangular. Labial segment III (second visible) thickest, apex proximal to the level of anterior margin of eye; segment IV longest. Thorax: fore lobe of pronotum approximately 1.15 times longer than hind lobe, subrectangular in dorsal view (Figs. 2, 6); anterior projections of collar rounded and prominent (Fig. 4); integument dull, rugose and transversely striated, dorsally and laterally; with a welldefined longitudinal medial shallow furrow, with rugose integument; transverse interlobar sulcus deep, thin and curved (Fig. 6). Hind lobe of pronotum shorter and larger than fore lobe; somewhat enlarged towards apical margin; integument mostly smooth, shiny, with faint transversal striations more numerous at distal portion, with a wide, distinct longitudinal shallow depression, enlarged at its median portion, not reaching basal and distal portions, with rugose integument (Figs. 2, 6); posterior margin with numerous longitudinal thin shallow ridges, forming a wrinkled integument; humeral angles with elevated rounded tubercles. Lateral margins of stridulitrum conspicuously protuberant. Scutellum moderately elevated, with a small median pointed horizontal prominence at its tip (Figs. 7-8). Metanotum with a short, pointed, horizontally directed backwards prominence (Figs. 7-8). Fore coxae and fore femora elongated, latter somewhat broadened at submedian basal portion (Fig. 3); fore tibia approximately half as long as fore femora, dorsally depressed approximately at basal portion of distal half, ventrally with a single series of hook-like denticles, which are absent at basal portion and extreme apex; inner surface on distal quarter somewhat flattened (Figs. 10-11). Mid and hind femora and tibiae very long and slender. Tarsi three-segmented, slender. Forewings approaching apex of abdomen and apex of genitalia by approximately 0.4 $\mathrm{mm}$ and $1.0 \mathrm{~mm}$, respectively; pygophore and about posterior half of tongue-shaped prolongation of last tergite exposed on dorsal view (Fig. 2); subbasal cell longer than basal cell; subbasal and discal cells clearly separated by basal cell (Figs. 13-14). Hind wings reaching distal portion of tergite VI; venation as in Fig. 15. Abdomen: first tergite subrectangular, elevated in relation to the following tergites, its spiracle beside the anterolateral margin; segment II narrow; segments III-V progressively slightly widened towards apex; segment VI slightly narrowed towards apex; segment VII more narrowed towards apex, dorsally with a tongue-shaped prolongation posteriorly, which is rounded apically, somewhat wider at base, ending at level of approximately middle third of pygophore (Figs. 16-17). Connexival 
segments simple, straight. Sternites I-VI with a median longitudinal thin and shallow carina. Eight sternite slightly enlarged toward apex, with posterior margin somewhat curved at ventral and laterosuperior portions, the latter, just below the spiracle (Figs. 17-18). Male genitalia (Figs. 16-35): pygophore subrectangular in dorsal and ventral views (Figs. 19-20); in dorsal view: between anterior and posterior genital openings, a narrow dorsal (transverse) almost straight bridge (br) (Fig. 19), proctiger (pc) subsquared to subrectangular, somewhat enlarged towards apex (Fig. 19); process of pygophore (pp) spine-like in dorsal, ventral and posterior views (Figs. 19-21), curved in lateral view (Fig. 23). Parameres symmetrical (Figs. 19-21), curved, with apical half enlarged, suboval in shape (Fig. 24); outer surface densely setose, not impressed on disc (Fig. 24A); inner surface less setose, with a pair of small pointed processes at its tip (Fig. 24B). Phallus (Figs. 25-27): articulatory apparatus with basal arms (ba) shorter than phallosoma, divergent, connected by a short and narrow basal bridge (Figs. 25-27); basal plate struts (bp) (Figs. 25-26, 29-30) elongated, generally narrow, strongly double curved in lateral view, in dorsal view: basal portion largely divided into two branches, more enlarged in the median portion and even narrower at distal half, the latter with its central portion deepened, bordered by narrow margins; apical extremity convergent, their sides somewhat asymmetrical, and covered by the basal portion of the sclerotization of the dorsal wall of phallosoma (sdw). The latter, short, subsquared, slightly asymmetrical, and located dorsally and partially over to the apical portion of basal plate struts (Figs. 25-26, 28, 30). An elongated median sclerotization of the ventral wall of phallosoma (svw) (Figs. 25, 27, 28, 35), which is shortly divided at extreme base and narrowed at approximately middle portion with apical margin continuous with apex of dorsal membranous wall (svwd) (Figs. 25-26, 28); Endosoma wall smooth. Endosoma with two processes: 1) a large, elongated, flat, subtriangular, somewhat sclerotized dorsal process (dps), with asymmetrically curved margins, enlarged at basal portion, which has a pair of narrow lateral branches; it is covered by a spiny membrane at approximately its basal third, and by several small spines at lateral portions of approximately its distal half, except at the apex, which is less sclerotized, rounded and smooth and is located short of apical portion of the dorsal phallothecal plate (Figs. 25-28, 31-33); 2) a basoventral moderately large process (bv) with a flat short narrow striate basomedian portion, surrounded by curved layers, which are distally connected with a pair of flat, narrow laminar portions (Figs. 25, 27, 34).

\section{Distribution. Ecuador.}

Comments. The inclusion of Ph. ecuadorensis sp. nov. in Phasmatocoris is in accordance with the characteristics assigned to this genus by Wygodzinsky (1966), Pape (2013) and Gil-Santana (2015). In this matter, it is noteworthy that Wygodzinsky (1966) argued that Phasmatocoris was distinguished from all other genera of Emesini by the considerably asymmetrical phallus. The asymmetry would often be perceptible in the phallosoma, especially in the shape of the basal plate struts and the overlying dorsal sclerotization of the phallosoma wall. The greatest degree of asymmetry, however, was found in the endosoma, especially on its apical portion, while the processes of endosoma are slightly to very strongly asymmetrical, varied in shape and number (Wygodzinsky 1966). However, the phallic structures of Ph. ecuadorensis sp. nov. are mostly symmetrical, with slight asymmetry in the apical portion of basal plate struts (bp) (Figs. 26, 30) and the sclerotization of dorsal wall of phallosoma (sdw) (Figs. 26, 30), albeit somewhat more prominent in this matter are the asymmetrically curved margins of the dorsal large process of endosoma (dps) (Figs. 31-33). On the other hand, in other five species of Phasmatocoris, Gil-Santana et al. (2007) and Gil-Santana (2015, 2018a) found a considerable range in the degree of asymmetry in the phallosoma and processes of the endosoma, from quite asymmetrical to basically symmetrical or only slightly asymmetrical. Therefore, the slight asymmetry recorded in phallic structures of Ph. ecuadorensis sp. nov. is in accordance 
with the observations of Gil-Santana $(2015,2018 a)$ that there is a range in the degree of the asymmetry in the phallic structures among the species of Phasmatocoris.
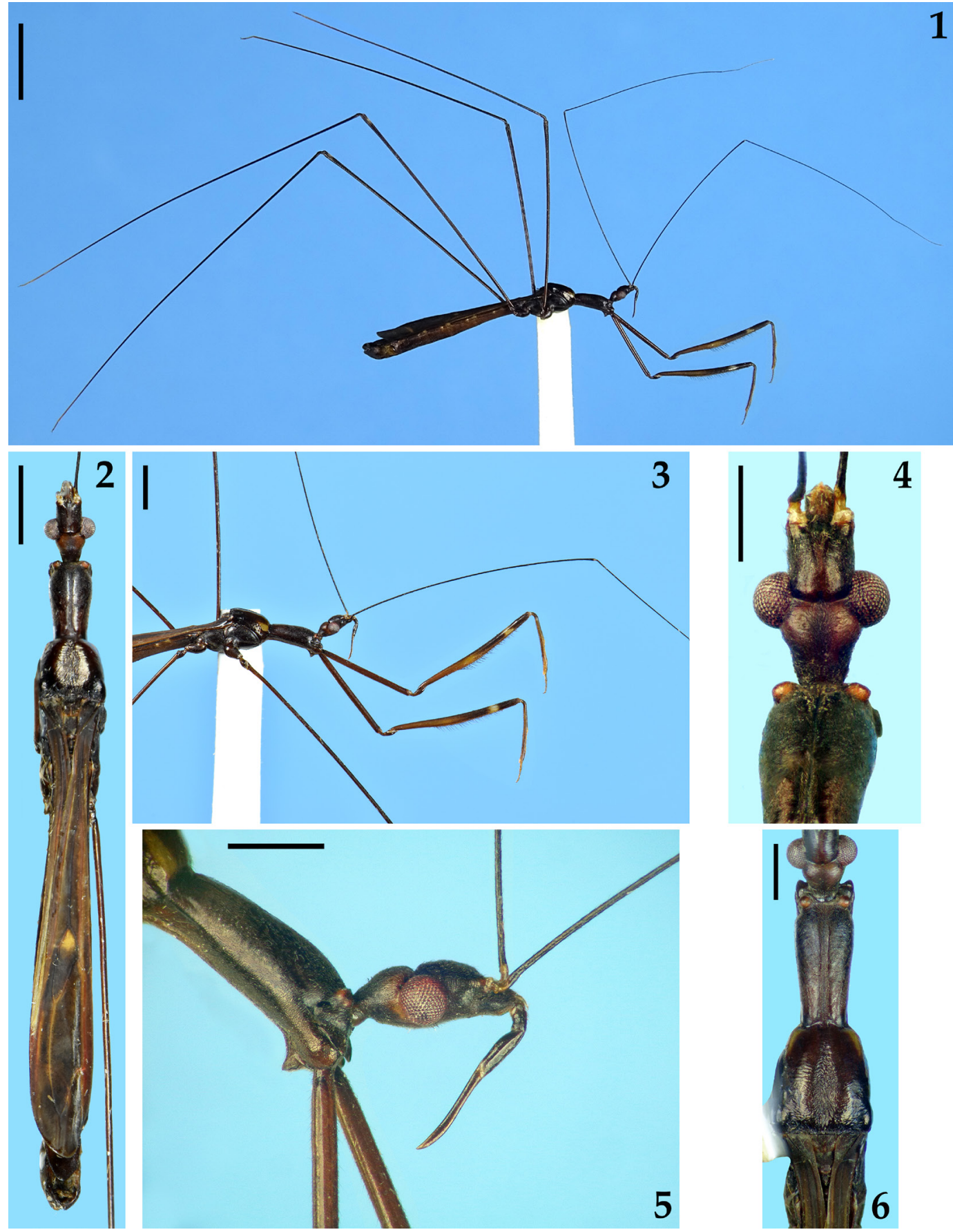

Figures 1-6. Phasmatocoris ecuadorensis sp. nov., male holotype. 1. Lateral view, scale bar 5.0 mm. 2-3. Scale bars $2.0 \mathrm{~mm}$. 2. Dorsal view, legs excluded, except hind right femur. 3. Head, thorax, fore legs and base of abdomen, lateral view. 4-6. Scale bars $1.0 \mathrm{~mm}$. 4 . Head and basal portion of fore lobe of pronotum, dorsal view. 5. Head and fore lobe of pronotum, lateral view. 6. Distal portion of head and thorax, dorsal view. 


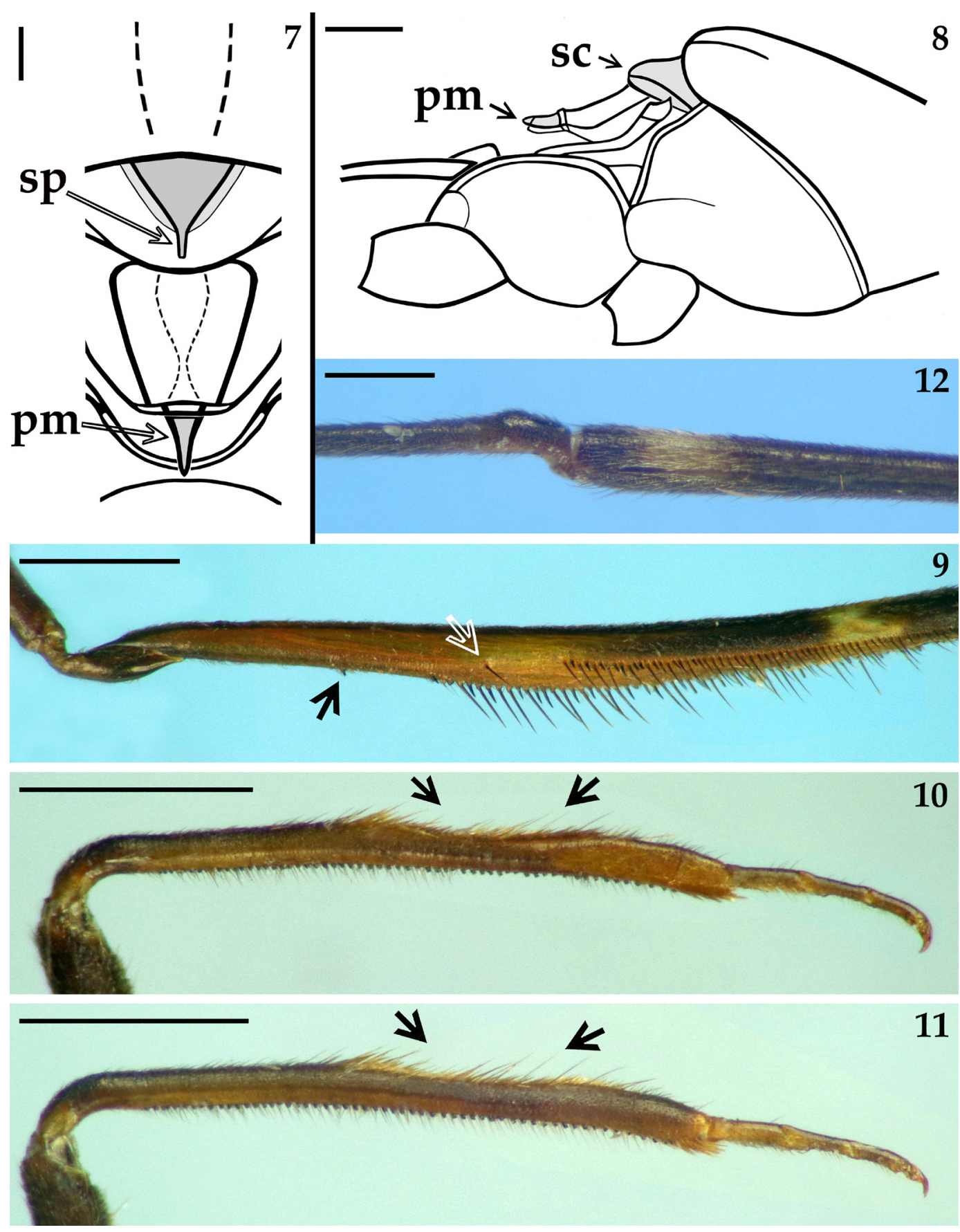

Figures 7-12. Phasmatocoris ecuadorensis sp. nov., male holotype. 7-8. Distal portion of pronotum, meso- and metathorax, wings set apart, schematic outline; sp, pointed prominence at tip of scutellum; $\mathrm{pm}$, pointed prominence of metanotum; sc, scutellum. 7. Median portion, dorsal view, scale bar 0.2 mm. 8. Lateral view, scale bar $0.5 \mathrm{~mm}$. 9-11. Left fore leg, lateral views, scale bars $1.0 \mathrm{~mm}$. 9. Distal portion of coxa, trochanter and femur, excluding apex, inner surface, white arrow points to isolated basal seta of anteroventral series; black arrow points to the additional [broken] setae between the base of the segment and the posteroventral series. 10-11. Apex of femur, tibia and tarsus, setae point to depressed area of tibia with stiff inclined setae. 10. Inner surface. 11. Outer surface. 12. Hind leg, apex of femur and base of tibia, lateral view, scale bar $0.5 \mathrm{~mm}$. 

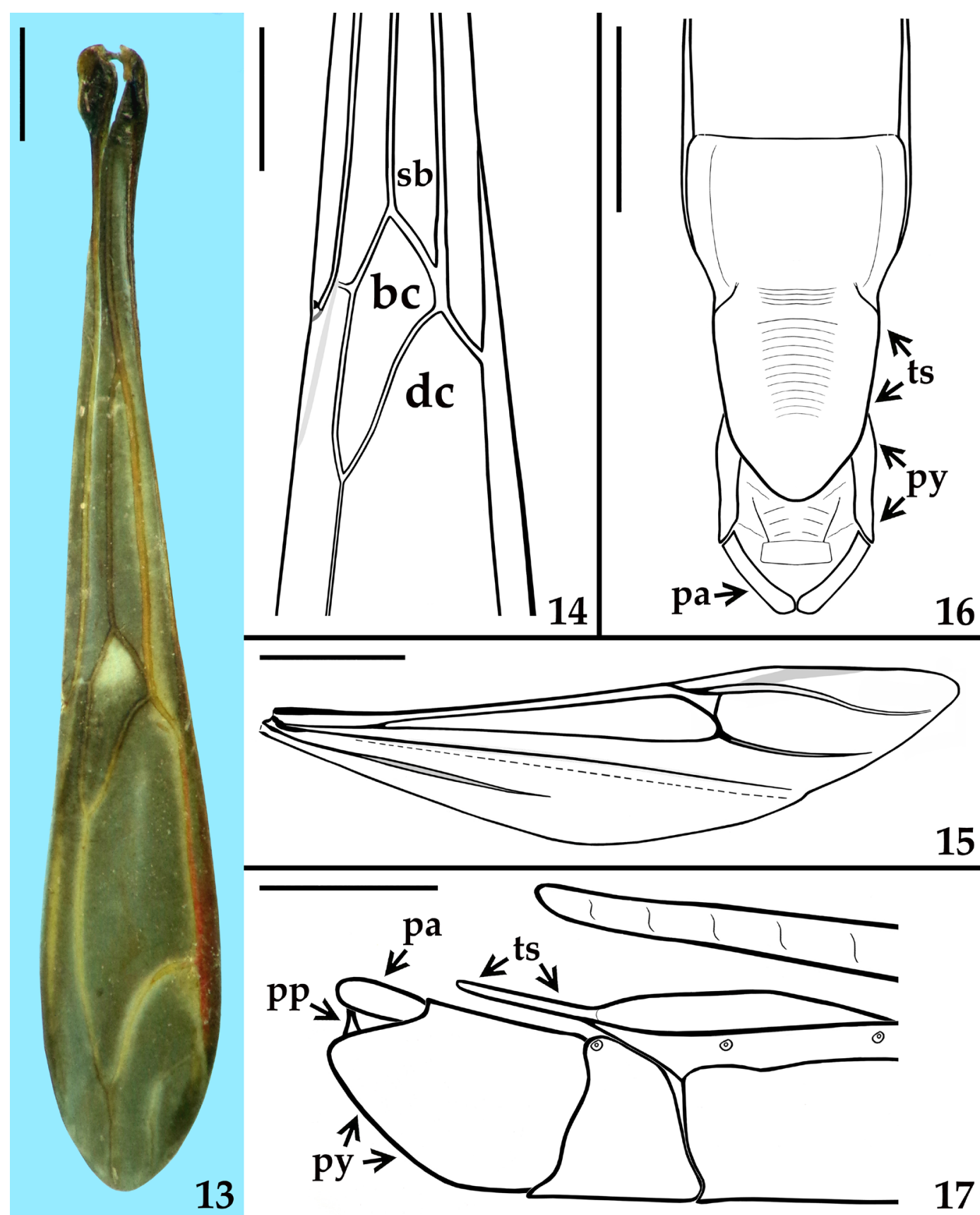

Figures 13-17. Phasmatocoris ecuadorensis sp. nov., male holotype. 13-16. Dorsal view. 13-14. Forewing, scale bars $1.0 \mathrm{~mm}$. 14. Median portion; sb, subbasal cell; bc, basal cell; dc, discal cell. 15. Hind wing, scale bar $2.0 \mathrm{~mm}$. 16-17. Distal portion of body, scale bars $1.0 \mathrm{~mm}$. 16. Hemelytra not included, dorsal view. 17, lateral view; pa, paramere; pp, process of pygophore; py, pygophore; ts, tongue-shaped prolongation of abdominal segment VII.

Phasmatocoris papei, the species which seems closer to Ph. ecuadorensis sp. nov., was recorded as presenting an overall similarity with Ph. moraballi Wygodzinsky, 1966 but also to Ph. magdalenae Wygodzinsky, 1966 and Ph. sturmi Wygodzinsky, 1966 (Gil-Santana 2018a). These three latter species were considered as closely related by Wygodzinsky (1966), who 
also referred to them as "a group" of "dark, medium-sized species around [Ph.] magdalenae", occurring in the Amazonian region. Phasmatocoris papei and Ph.ecuadorensis sp. nov. also belong to this group, but they can be separated from the other three species by the characteristics mentioned in the following key. Additionally, the phallic structures such as the shape of basal plate struts (bp) and specially the processes of the endosoma are very different among $P h$. magdalenae, Ph. sturmi, Ph. papei and Ph. ecuadorensis sp. nov. (Wygodzinsky 1966; Gil-Santana 2018a; figs. 25-34). Yet, the processes of endosoma of Ph. magdalenae, Ph. moraballi and Ph. sturmi were recorded as strongly or clearly asymmetrical by Wygodzinsky (1966), while only a slight asymmetry was recorded in some of the structures of the endosoma of $\mathrm{Ph}$. papei (Gil-Santana 2018a), similarly to Ph. ecuadorensis sp. nov., with the exception of the more asymmetrically curved margins of the dorsal large process of endosoma (dps) (Figs. 31-33). On the other hand, while the sclerotization of the ventral wall of phallosoma and the shape of the basal plate struts of $\mathrm{Ph}$. papei seemed to be similar to those of Ph. praecellens (Gil-Santana 2018a) (see below), the sclerotization of the ventral wall of phallosoma of Ph. ecuadorensis sp. nov. is partially similar to that of Ph. praecellens (Wygodzinsky 1966: fig. 86L), whereas an elongated, narrow basal plate struts, as found in Ph. ecuadorensis sp. nov. (Figs. 26, 29-30) was also recorded in Ph. borgmeieri (Wygodzinsky, 1945) (Gil-Santana 2015: fig. 13). In the latter species, the "flat process" of endosoma, as recorded by Gil-Santana (2015: figs. 11, 14), seems to be actually a shorter sclerotization of the ventral wall of phallosoma similar to that of $P h$. ecuadorensis sp. nov. (Figs. 27, 35). In this case, the alleged asymmetry of the two "processes" of the endosoma of Ph. borgmeieri (Gil-Santana, 2015) would have been a misinterpretation of this latter author in which only the tubular process (his Figs. 15-16) should be considered as such and, therefore, a symmetrical process of the endosoma.

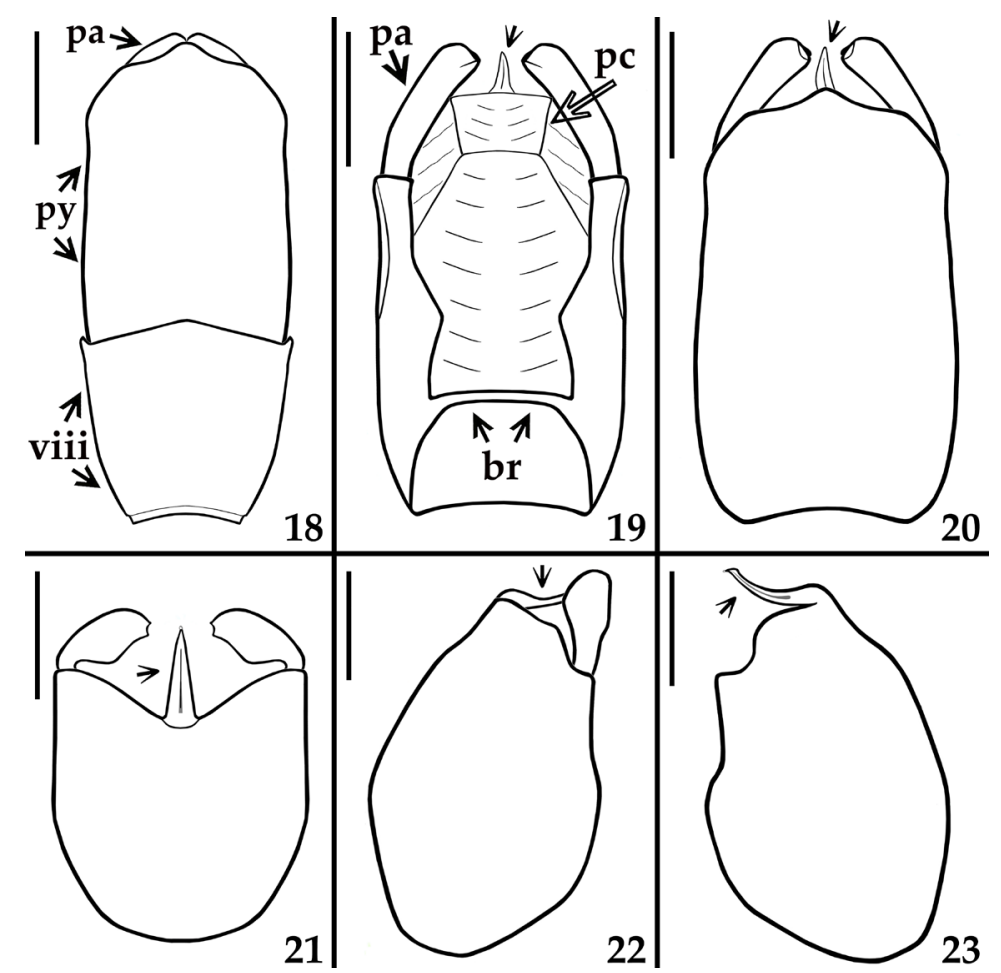

Figures 18-23. Phasmatocoris ecuadorensis sp. nov., male holotype, scale bars $0.5 \mathrm{~mm}$. 18. Abdominal segment VIII and pygophore, ventral view. 19-22. Pygophore, parameres slightly moved apart. 19. Dorsal view 20. Ventral view. 21. Posterior view. 22. Lateral view. 23. Pygophore without parameres, lateral view; br, transverse bridge; pa, parameres; pc, proctiger; py, pygophore; viii, segment abdominal VIII; small seta points to process of pygophore. 
In any case, the characters of the male genitalia of Ph. ecuadorensis sp. nov. reinforce Wygodzinsky's (1966) concept of this genus, based on the particular structure of the male genitalia, as the new species shares similarities with various species in the genus, in a mixed way, despite conspicuous differences in other characters.

The depression on the dorsal surface of the fore tibiae, covered with medium-sized stiff dense setae, which was recorded in other species of Phasmatocoris (Forero 2006; Pape 2013; Gil-Santana 2015, 2018a) and compatible with the calamistrum-like structure described by Wygodzinsky (1966) in many emesines was observed in Ph. ecuadorensis sp. nov. (Figs. 10-11) too.
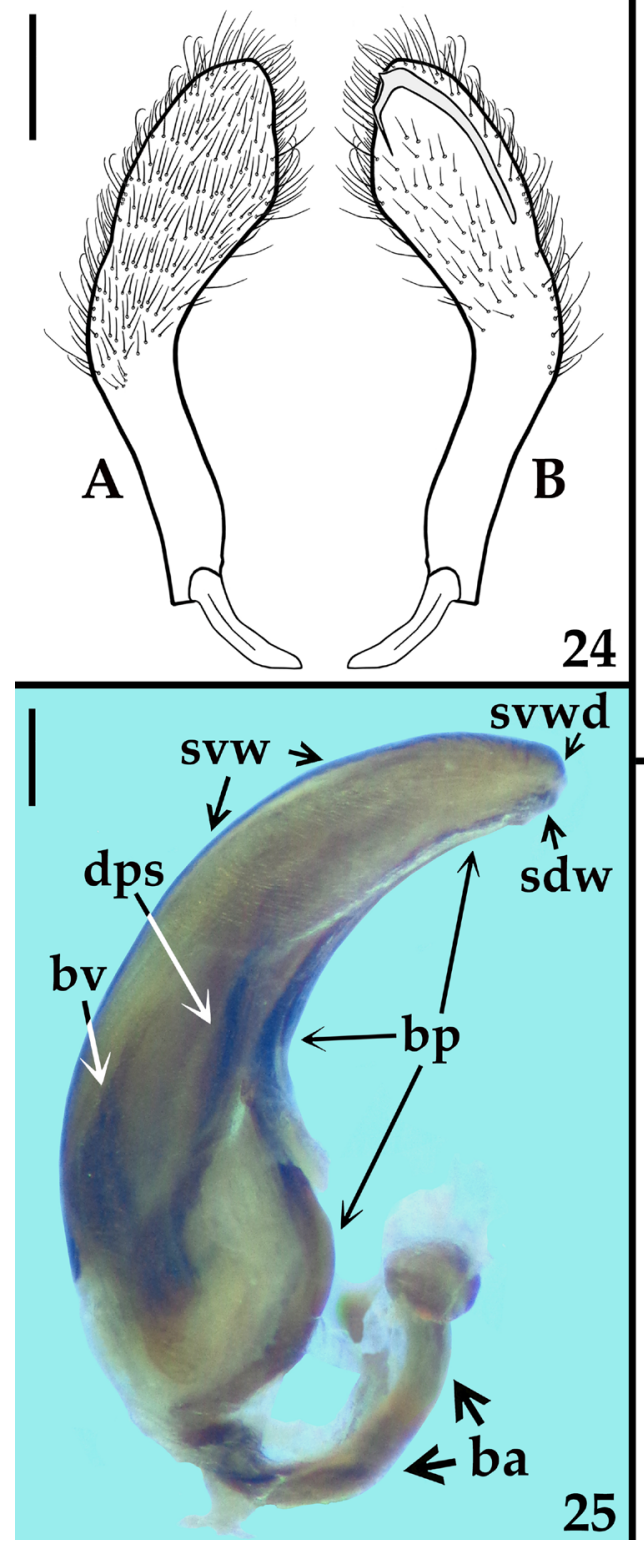

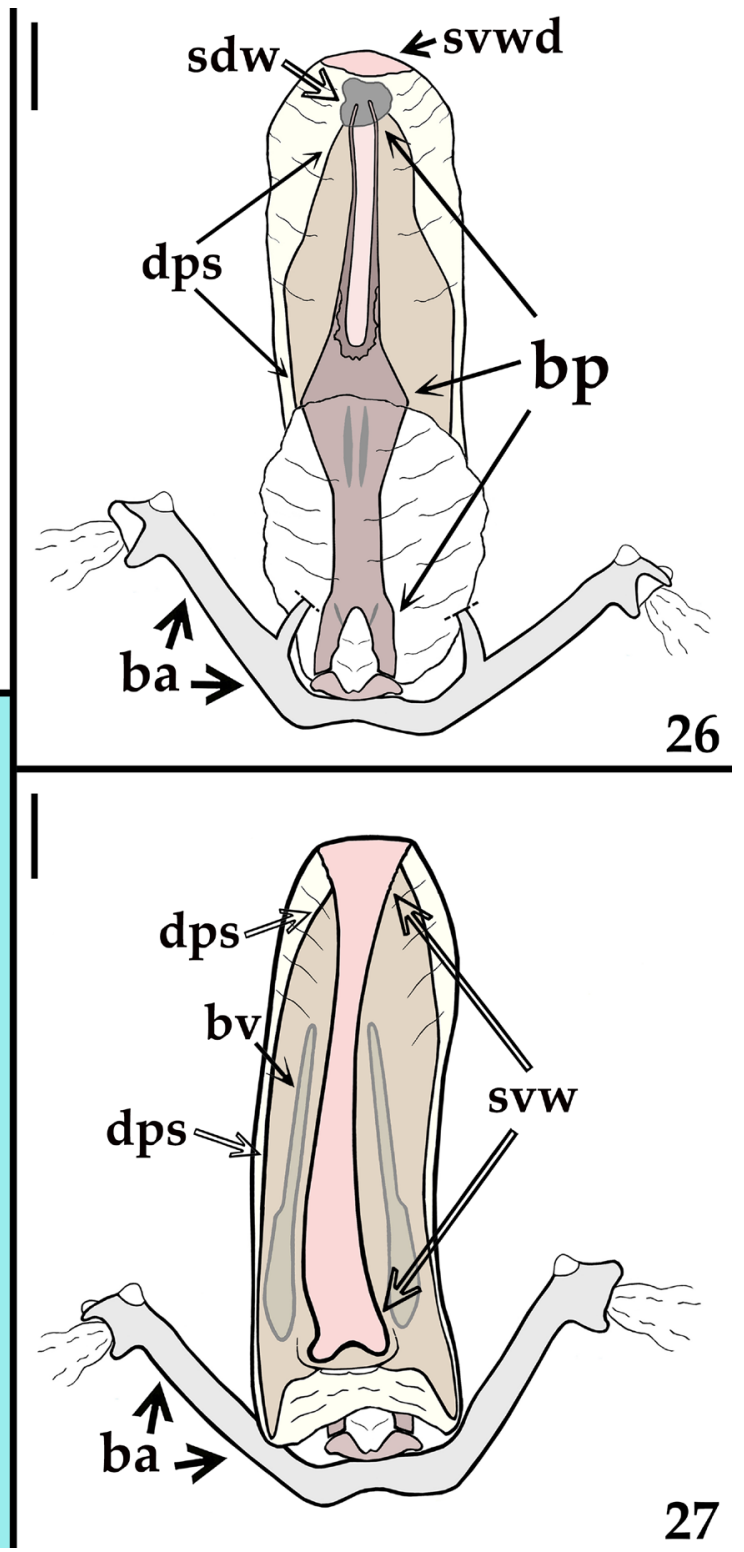

Figures 24-27. Phasmatocoris ecuadorensis sp. nov., male genitalia, scales bars $0.2 \mathrm{~mm}$. 24. Left paramere, A, outer surface, B, inner surface. 25-27. Phallus. 25. Lateral view. 26. Dorsal view. 27. Ventral view; ba, basal arm; bp, basal plate struts; dps, dorsal process of endosoma; bv, basoventral process of endosoma; sdw, sclerotization of the dorsal wall of phallosoma; svw, median sclerotization of the ventral wall of phallosoma; svwd, same as the latter but the portion which reaches dorsal apex of phallosoma. 


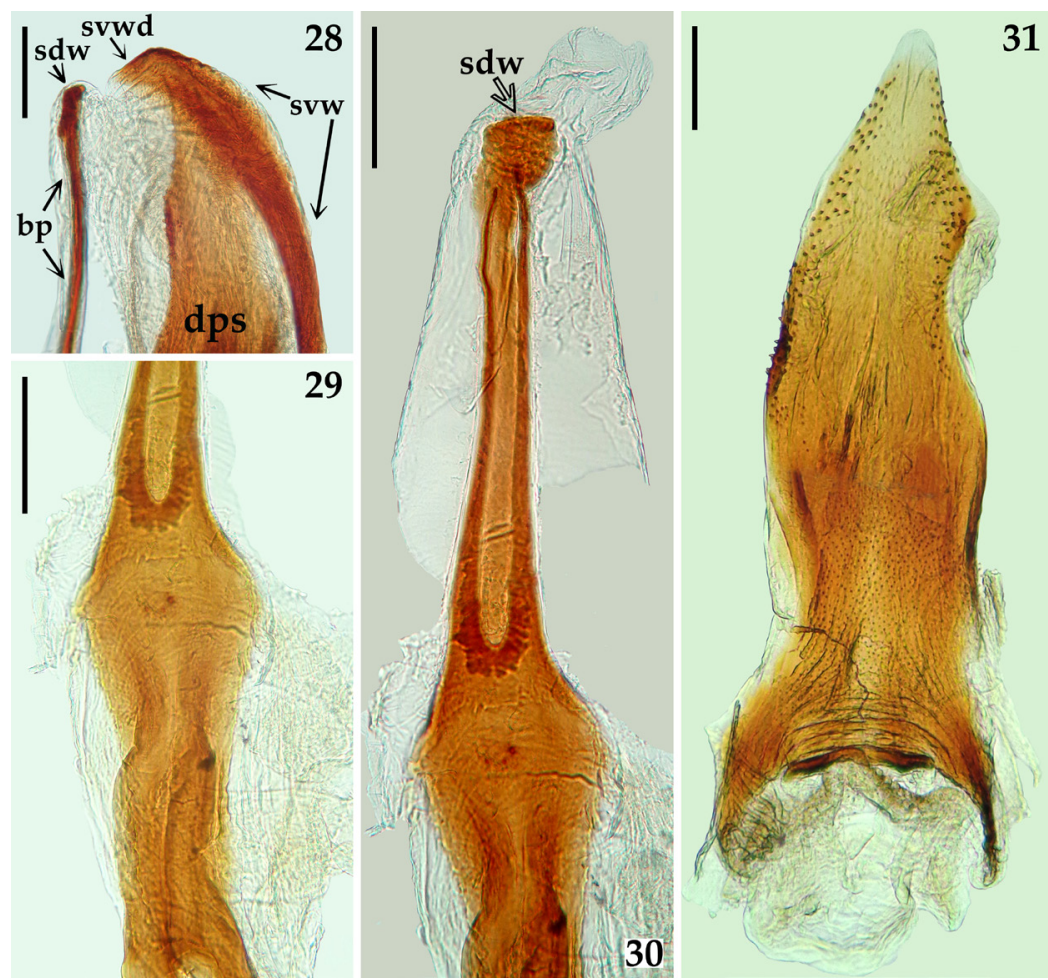

Figures 28-31. Phasmatocoris ecuadorensis sp. nov., male genitalia, scales bars $0.2 \mathrm{~mm}$. 28. Phallus, apical portion, lateral view. 29-31. Dorsal view. 29-30. Basal plate struts. 29. Middle half. 30. Distal two-thirds; bp, basal plate struts, dps, dorsal process of endosoma; sdw, sclerotization of the dorsal wall of phallosoma; svw, median sclerotization of the ventral wall of phallosoma; svwd, same as the latter but the portion which reaches dorsal apex of phallosoma. 31. Dorsal process of endosoma.

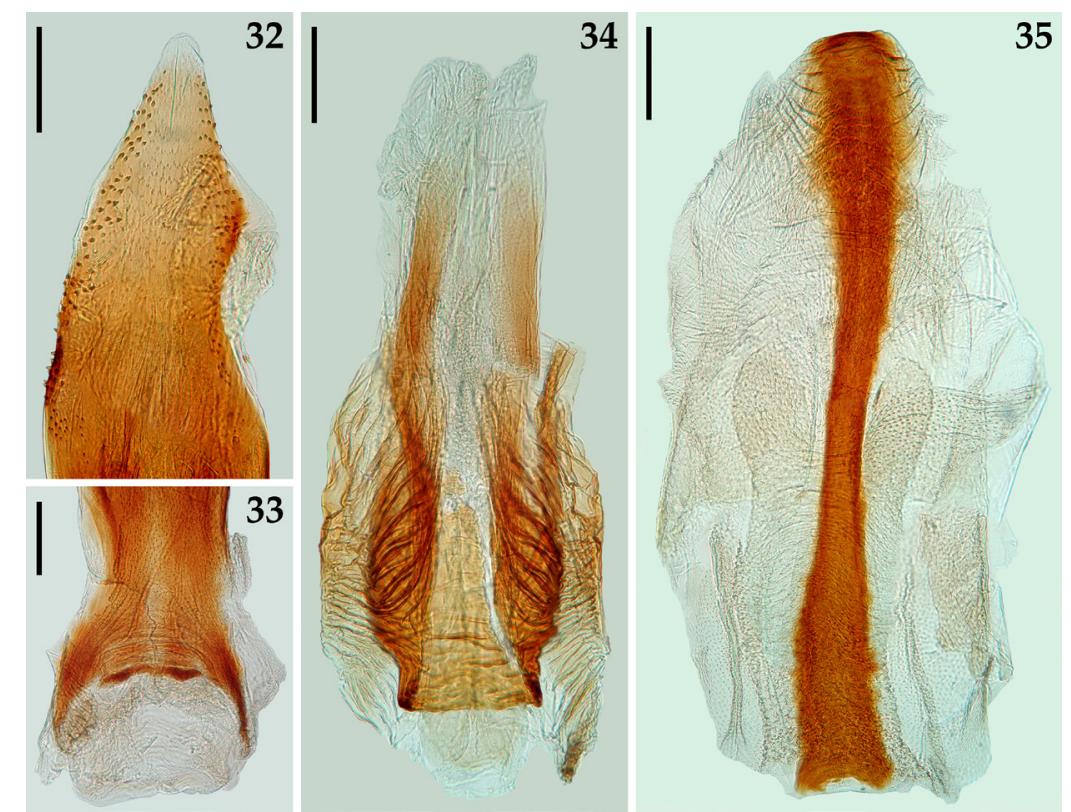

Figures 32-35. Phasmatocoris ecuadorensis sp. nov., male genitalia, scales bars $0.2 \mathrm{~mm}$. 32-34. Dorsal view. 32-33. Dorsal process of endosoma. 32. Distal two-thirds. 33. Basal third. 34. Basoventral process of endosoma. 35. Ventral wall of phallosoma, including its elongated median sclerotization. 


\section{Phasmatocoris praecellens (Bergroth, 1911)}

(Figs. 36-39)

Type material. Myiagreutes praecellens Bergroth, 1911. [FMNH], Syntype o: [handwritten:] Myiagreutes / praecellens / Bergr. $q$ / / French / Guiana / / [bordered label:] [handwritten:] Emesa / (Myiagreutes) / praecellens / Bergr. [printed at left, below:] Det McAtee / and Malloch / / [printed red label:] SYNTYPE / / [printed blue label:] Photographed / 2019 / Pekka Malinen / / [printed label:] [at left:] QR Code [at right:] http: / / id.luomus.fi / / GZ.45901 / FRENCH GUAIANA.

Myiagreutes and M. praecellens were described by Bergroth (1911) based on a single female specimen from French Guiana (Figs. 36-39). Despite the differences in the armature of the fore femora of Myiagreutes and Phasmatocoris, "the similarity of the highly specialized male genitalia" of Ph. praecellens and Ph. spectrum Breddin, 1904 indicated the synonymy between these genera (Wygodzinsky 1966). As an additional evidence, when describing Ph. papei, Gil-Santana (2018a) recorded that the basal plate struts of Ph. praecellens (cf. Wygodzinsky 1966: fig. 86O) seemed quite more similar to that of Ph. papei (Gil-Santana 2018a: figs. 2829) than that of Ph. spectrum (Wygodzinsky 1966: fig. 87P), while the sclerotization of the ventral wall (Gil-Santana 2018a: figs. 26, 30, Gil-Santana 2018b: figs. 1-2) of Ph. papei seemed similar to that of Ph. praecellens (Wygodzinsky 1966: fig. 86L). These additional similarities support the synonym proposed by Wygodzinsky (1966) (Gil-Santana 2018a).
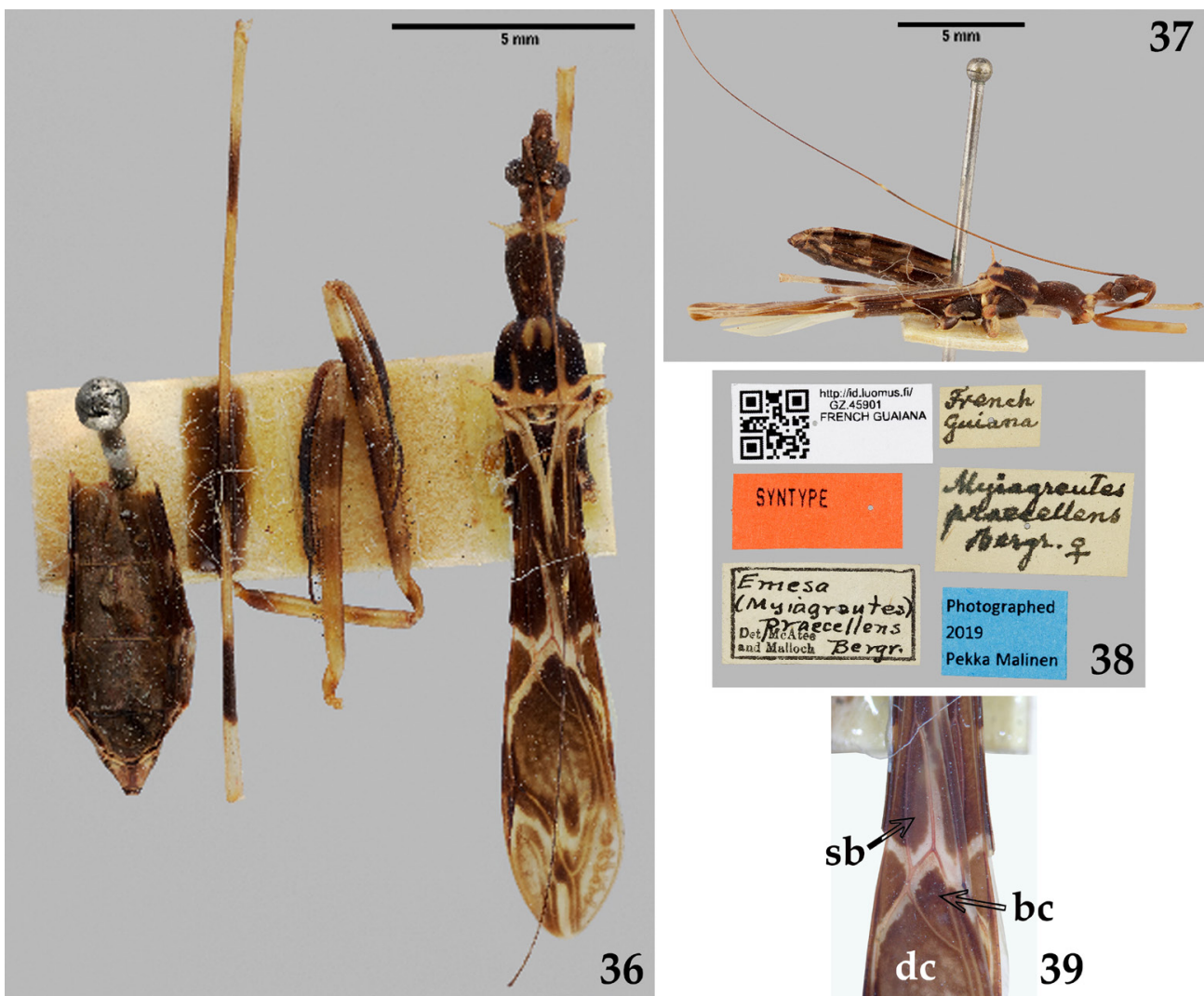

Figures 36-39. Myiagreutes praecellens Bergroth, 1911, syntype female, deposited in FMNH. 36-38. Photographs taken by Pekka Malinen and supplied by Heidi Viljanen (FMNH). 36. Dorsal view, some portions of legs and part of abdomen. 37. Lateral view. 38. Labels. 39. Forewing, median portion, dorsal view; sb, subbasal cell; bc, basal cell; dc, discal cell. 
Wygodzinsky (1966) recorded superficially identical males of Ph. praecellens showing differences in their phalli indicating that there are possibly two different species indistinguishable by external characters. However, because the holotype of Ph. praecellens is a female, it cannot be assigned to any of these two potential species (Gil-Santana 2018a).

Gil-Santana (2018a) examined a female from French Guiana which showed extensive pale markings, which agreed with the original description of the species (Bergroth 1911) and also with the holotype examined here (Figs. 36-37), while the basal cell of forewing did not separate subbasal and discal cells with the base of the latter narrowly meeting apex of the former (Gil-Santana 2018a: figs. 36, 38). On the other hand, the specimen of Ph. praecellens figured by Wygodzinsky (1966: plate 2, fig. 2) seems darker, with fewer pale markings, while his schematic drawing of the forewing of this species (Wygodzinsky 1966: fig. 86C) clearly shows the subbasal and discal cells being largely separated by a basal cell, what was recorded in the forewing of the holotype too (Fig. 39). Therefore, there is a need to examine more specimens of this species in order to clarify if these differences are part of an intraspecific variation or characteristics of different species as suggested by Wygodzinsky (1966).

In regard to the depression on the dorsal surface of the fore tibiae, covered with mediumsized dense stiff setae, compatible with the calamistrum-like structure (Wygodzinsky 1966), it had already been recorded in Ph. praecellens (Wygodzinsky 1966; Gil-Santana 2018a), and it was confirmed once more by examining the syntype of this species.

\section{Key for the species of Phasmatocoris, modified from Wygodzinsky (1966) and Gil- Santana $(2015,2018 a)$ :}

1. Ventral surface of fore femora with slender, spinelike setae only; anterolateral projections of collar rounded-truncate apically; metanotum with or without spine ........................ 3

- Ventral surface of fore femora with short, spiniferous processes in addition to spinelike setae; anterolateral projections of collar with long and slender, spinelike processes; metanotum spined .....

2. Pronotum with a median and a pair of humeral spines posteriorly (always distinct, though in some cases short); posteroventral series of fore femur with six or more large, spiniferous processes Ph. praecellens (Bergroth, 1911)

- Hind margin of pronotum lacking spines; posteroventral series of fore femur with at most five large, spiniferous processes Ph. minor (McAtee \& Malloch, 1925)

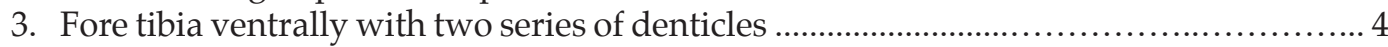

- Fore tibia ventrally with a single series of denticles .................................................. 7

4. Size, almost $20 \mathrm{~mm}$; general color testaceous, abdomen ochraceous; hind lobe before posterior margin with one median, and a pair of humeral toothlike processes. Parameres of male strongly widened apically Ph. spectrum Breddin, 1904

- Size, less than $15 \mathrm{~mm}$; general color stramineous to ochraceous; hind lobe lacking processes before posterior margin or with a very small, low, excavated protuberance at middle of posterior margin. Parameres of male pointed or rounded apically ............ 5

5. Portion of anteroventral series of fore femur situated basad of interruption consisting of one isolated seta; posterior margin of hind lobe with a very small, low, excavated protuberance at its middle. Parameres of male blunt-rounded apically ....

Ph. labyrinthicus Pape, 2013

- Portion of anteroventral series situated basad of interruption consisting of several setae forming an apparent continuation of posteroventral series; posterior margin of hind lobe without protuberances. Parameres of male pointed apically ....

6. Length, more than $10 \mathrm{~mm}$; pronotum testaceous, fore and hind lobe concolorous; head twice as long as high in lateral view; teeth of under surface of fore tibia hook-shaped; 
subbasal cell of forewing more than twice as long as basal cell

Ph. patquianus Wygodzinsky, 1966

- Length, much less than $10 \mathrm{~mm}$; fore lobe of pronotum ochraceous, hind lobe castaneous; head one and one-half times as long as high in lateral view; teeth of under surface of fore tibia peg like; subbasal cell of forewing less than twice as long as basal cell

Ph. usingeri Wygodzinsky, 1966

7. Spine-like setae of fore femur extending to, or almost to, base of femur ..................... 8

- Spine-like setae of fore femur not reaching base of femur, separated from base at least by about length of fore tarsus

8. Subbasal cell of forewing shorter than basal cell; fore lobe of pronotum more or less horizontal in lateral view Ph. testaceus (McAtee \& Malloch, 1925)

- Subbasal cell of forewing longer than basal cell; fore lobe of pronotum strongly declivous in lateral view ..................................... Ph. diffinis (McAtee \& Malloch, 1925)

9. Total length 22.2-24.0 mm. With conspicuous pale, reddish and darkened markings or portions, including reddish markings on head; lateral portions of thorax and a medial band on hind lobe of pronotum brownish; mid and hind femora and tibiae dark reddish, with femorotibial articulations largely whitish ............ Ph. catarinae Gil-Santana, 2015

- Total length 11-17.5 mm. Body with less conspicuous markings, or without markings; all or at least the mid-femorotibial articulations with the same color of the leg or apical portion of mid and hind femora darkened

10. General color ferruginous to testaceous; metanotum tuberculate behind but without spine; posterior process of pygophore broad and platelike or spine-like ................................. 11

- General color piceous, blackish, brownish-black or yellow-orange to testaceous; metanotum with a short spine or small blunt tubercle or elevation; posterior process of pygophore spine-like

11. Fore lobe of pronotum very slightly longer than hind lobe; posterior process of pygophore broad and plate-like.

- Fore lobe of pronotum 1.6 to 1.7 times longer than hind lobe; posterior process of pygophore spine-like Ph. borgmeieri (Wygodzinsky, 1945)

12. Portion of anteroventral series situated basad of interruption consisting of a single isolated seta; posterior process of pygophore not continuous with surface of pygophore, very short and broad, almost semicircular in outline .... Ph. rapax (McAtee \& Malloch, 1925)

- Portion of anteroventral series of fore femur situated basad of interruption consisting of several spiniform setae forming an apparent continuation of posteroventral series; process of pygophore continuous with surface of pygophore, subrectangular in shape .....

Ph. breddini Wygodzinsky, 1966

13. General color yellow-orange to bright testaceous or testaceous to light brownish; metanotum with small blunt tubercle .... 14

- General color piceous, blackish, brownish-black; metanotum with a short but distinct spine or a pointed prominence.

14. General color yellow-orange to bright testaceous; distal half of fore femora, hind femora and tibiae darkened; pygophore with lateral notch at upper margin and posterior process elongated on posterior view; paramere without protuberance on inner surface; last sternite of female with a conspicuous apical median spine

Ph. xavieri Gil-Santana, Alves, Barrett \& Costa, 2007

- General color testaceous to light brownish; distal third of fore femora, apical portion of hind femora and basal portion of hind tibiae pale, somewhat yellowish; pygophore with upper margin straigh and posterior process short, subtriangular on posterior view; paramere with an apical large rounded protuberance on upper portion of inner surface; last sternite of female slightly acute at median portion of apex 
15. Shape of apical portion of parameres subrectangular or suboval (Fig. 24); posterior process of pygophore regularly narrowed from base to apex in posterior view (Fig. 21) ............. 16

- Shape of apical portion of parameres subtriangular; posterior process of pygophore somewhat constricted beyond base, slightly widened toward middle and again narrowed

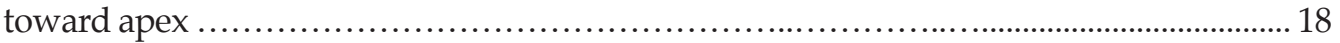

16. Hind lobe of pronotum with an almost imperceptible longitudinal depression. Basal cell of forewing not completely separating subbasal and discal cells, base of the latter narrowly meeting apex of the former. Apical portion of parameres subrectangular, their outer surface somewhat impressed on disc .......................................... Ph. moraballi Wygodzinsky, 1966

- Hind lobe of pronotum with a wide, distinct longitudinal depression (Fig. 6). Subbasal and discal cells of forewing clearly separated by basal cell (Figs. 13-14). Apical portion of parameres suboval, with a pair of pointed processes at tip of inner surface (Fig. 24B); their outer surface not impressed on disc (Fig. 24A) ......................................... 17

17. Total length of male: $17.5 \mathrm{~mm}$; angles of collar of fore lobe of pronotum dark reddish (Fig. $4)$; anterolateral angles of hind lobe of pronotum with a subtriangular dark yellowish spot (Fig. 3); fore femora with a subdistal pale annulus (Figs. 3, 9); hind femora with subapical narrow yellowish spots, on lateral and dorsal surfaces (Fig. 12); forewings with the basal third of basal cell pale whitish and pale markings adjacent to veins of discal cell (Fig. 13); metanotum with a short, pointed, horizontally directed backwards prominence (Fig. 7); process of pygophore curved in lateral view (Fig. 23) ....

Ph. ecuadorensis sp. nov.

- $\quad$ Total length of male: 12.5-13.7 mm; fore and hind lobes of pronotum completely dark blackish, without paler portions of markings; subdistal and subapical portions of fore and hind femora without annulus or spots, respectively; forewings dark brown, without pale markings; metanotum with a short obliquely elevated spine; process of pygophore, generally straight in lateral view ...................................... Ph. papei Gil-Santana, 2018

18. Distance from apex of antenniferous tubercles to anterior border of eyes, in lateral view, somewhat less than length of eyes; parameres not indented dorsally before apex

Ph. sturmi Wygodzinsky, 1966

- Distance from apex of antenniferous tubercles to anterior border of eyes, in lateral view, somewhat greater than length of eyes; parameres indented dorsally before apex Ph. magdalenae Wygodzinsky, 1966

\section{Conclusion}

The modifications of the fore tibiae (the depression on the dorsal surface of the fore tibiae, covered with medium-sized stiff dense setae, compatible with the calamistrum-like structure) recorded by previous authors (Forero 2006; Pape 2013; Gil-Santana 2015, 2018a) were recorded in the new species described here (Figs. 10-11). Therefore, the calamistrumlike structure occurs at least in several species of Phasmatocoris, but its presence or absence has remained undocumented in many species of the genus. The presence of this structure suggests a potential arachnophilous association, but currently no field observation is available about the bionomics of these species (Gil-Santana 2018a).

With the new species described here, 19 species are now included in Phasmatocoris, and this genus is recorded for the first time from Ecuador.

\section{Acknowledgements}

I am grateful to Heidi Viljanen (FMNH) for allowing me to examine and photograph specimens from her Institution; and I am also thankful to her and Pekka Malinen for the photographs of the syntype of Myiagreutes praecellens Bergroth deposited in FMNH. 


\section{Literature Cited}

Bergroth, E. (1911) New Neotropical Plœariinæ. Psyche, 18: 15-20. https://doi. org $/ 10.1155 / 1911 / 123920$

Forero, D. (2006) New records of Reduviidae (Hemiptera: Heteroptera) from Colombia and other Neotropical countries. Zootaxa, 1107: 1-47.

Froeschner, R.C. (1981) Heteroptera or true bugs of Ecuador: a partial catalog. Smithsonian Contributions to Zoology, 322: 1-147.

Gil-Santana, H.R. (2015) Two new species of Phasmatocoris Breddin from Brazil, and description of the male of Phasmatocoris borgmeieri (Wygodzinsky) (Hemiptera: Heteroptera: Reduviidae: Emesinae). Zootaxa, 4059(1):51-70. https:/ / doi.org/10.11646/ zootaxa.4059.1.3

Gil-Santana, H.R. (2018a) A new species of Phasmatocoris from French Guiana, with short taxonomic notes on two described species and an updated key (Hemiptera: Heteroptera: Reduviidae: Emesinae). Zootaxa, 4413(3): 491-506. https://doi.org/10.11646/ zootaxa.4413.3.4

Gil-Santana, H.R. (2018b) Corrigenda to Gil-Santana, H.R. 2018. A new species of Phasmatocoris from French Guiana, with short taxonomic notes on two described species and an updated key (Hemiptera: Heteroptera: Reduviidae: Emesinae). Zootaxa, 4413(3): 491-506. Zootaxa, 4483(1): 194-196. https:/ / doi.org/10.11646/ zootaxa.4483.1.10

Gil-Santana, H.R., Alves, V.R., Barrett, T.V. and Costa, L.A.A. (2007) A new species of Phasmatocoris Breddin (Hemiptera: Reduviidae: Emesinae) from the Amazon, Brazil. Zootaxa, 1642: 43-51.

Lent, H. and Wygodzinsky, P. (1979) Revision of the Triatominae (Hemiptera: Reduviidae) and their significance as vector of Chagas's disease. Bulletin of the American Museum of Natural History, 163: 123-520.

Maldonado, J.C. (1990) Systematic catalogue of the Reduviidae of the world (Insecta: Heteroptera). Caribbean Journalof Science University of Puerto Rico, Special Edition: 1-694.

Pape, R.B. (2013) Description and ecology of a new cavernicolous, arachnophilous threadlegged bug (Hemiptera: Reduviidae: Emesini) from Kartchner Caverns, Cochise County, Arizona. Zootaxa, 3670(2): 137-156. https:/ / doi.org/10.11646/ zootaxa.3670.2.2

Weirauch, C. (2008) From four- to three- segmented labium in Reduviidae (Hemiptera: Heteroptera). Acta Entomologica Musei Nationalis Pragae, 48: 331-344.

Wygodzinsky, P.W. (1966) A monograph of the Emesinae (Reduviidae, Hemiptera). Bulletin of the American Museum of Natural History, 133: 1-614. 